\title{
Towards a blockchain-based framework for traceability in compliance with GS1
}

\author{
Hoai-Nam Nguyen ${ }^{1,2}$, Minh-Thinh Le ${ }^{1,2}$, Duc-Hiep Nguyen ${ }^{1,2}$, Thanh-Van Le ${ }^{1,2}$, Huynh-Tuong Nguyen ${ }^{1,2}$, \\ Hoang-Anh Pham ${ }^{1,2, *}$
}

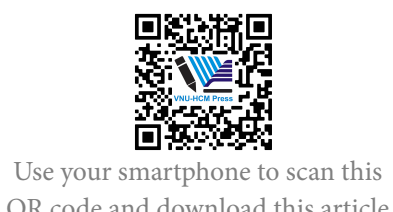

QR code and download this article

${ }^{1}$ Ho Chi Minh City University of

Technology, Vietnam

${ }^{2}$ Vietnam National University Ho Chi Minh City, Vietnam

Correspondence

Hoang-Anh Pham, Ho Chi Minh City University of Technology, Vietnam

Vietnam National University Ho Chi Minh City, Vietnam

Email: anhpham@hcmut.edu.vn

History

- Received: 27-7-2019

- Accepted: 23-8-2019

- Published: 17-10-2020

DOI :10.32508/stdjet.v3iSI1.514

\section{Check for updates}

\section{Copyright}

(c) VNU-HCM Press. This is an openaccess article distributed under the terms of the Creative Commons Attribution 4.0 International license.

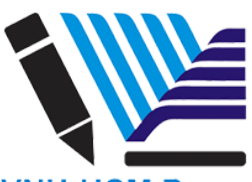

\begin{abstract}
Traceability not only meets the social needs of product information transparency and reinforces the trust of consumers, but also meets the needs of enterprises for brand protection and enhances the competition in markets. Since a traceability system collects every necessary information at every stage in a supply chain, it is also an efficient tool for monitoring and optimizing the production procedure. Adopting information technology to digitalize the business process is an inevitable trend to improve the efficiency in information management and especially quickly detect fraud problems. However, with the digitized process via a computer software system, the challenge remains as to whether digitized data is real. The reality shows that changing digital data is easier than paper-based data. Thus, it is necessary to have a digitalized process and a secure mechanism for ensuring transparency, correctness, and consistency of data leading to more efficiency in incidents detection and trace problems tracing. An emerging technology, Blockchain, has attracted more attention after its great success in finance due to various dominant features in preventing data changes even from the internal system. Technically, Blockchain is a ledger that records the entire transaction history publicly on a network of peer-to-peer computers of the time. One common ledger will be shared among all collaborative organizations in an ecosystem to ensure data immutability and undeniable responsibility, thereby enhancing data transparency. Therefore, applying Blockchain technology in agriculture will improve the current traceability process, aiming to increase the responsibility of the objects in the process and transparency of information for consumers. In this paper, we propose a framework that utilizes Blockchain to robustize traceability systems. Additionally, our proposed framework is compliant with the GS1 standard to achieve high reliability and compatibility on a global scale.
\end{abstract}

Key words: Traceability, Blockchain, Trust, Transparency

\section{INTRODUCTION}

Nowadays, a traceability system has great importance in industries and social institutions, especially in the food industry ${ }^{1-6}$. The recent development of the traceability system has revealed the benefits that it could bring. It not only helps for traceability but also assists in branding, product quality, optimizing production processes, distributing, finding loopholes or reaching more customers, and taking competitive advantages depending on how the company utilizes the traceability system. More specifically, based on data collected by the traceability system, the parties know and reduce the consequences of flawed products as well as the source company will reduce costs and means of recovery in the event of defective. Managing product traceability aims to promote the socialization of traceability to serve international integration and improve efficiency in management, ensuring the quality and safety of products and goods. Therefore, it is appropriate to develop effective technology solutions applied in product traceability following the global development trend.

In recent years, consumer confidence in products and goods has been severely damaged by incidents of unknown origin. Therefore, many companies and manufacturers have developed plans to implement "QRcode" traceability for their products. However, accessing product information still faces many limitations such as incomplete retrieval information for the entire chain, no cross-checking of information and connection between agents, no unique identification system for products, no-verifying information, and no interactions between users.

To tackle these limitations, our work aims to build a decentralized, potential traceability solution across the entire global chain by leveraging the advantages of blockchain technology. The system has to ensure data always being available whenever needed, quickly, and accessible. Additionally, information can be verified at anytime, anywhere in the supply chain (e.g., at the 3(S1):SI10-SI16. 
distribution system, at the gate, at the seller, or the receiving place). Moreover, the last but not the least is to ensure transparency in the source information.

\section{RELATED WORKS}

\section{Traceability System}

Although being defined by various resources from international standards, law, and universal dictionary, traceability system is a model that has essential components including:

- Traceable resource units: Components and raw materials are grouped into units of similar features. This resource unit can be any traceable object. There are basic types called trade units (e.g., case, bottle, box, or bag) or logistic unit (e.g., pallet or container) or production unit (e.g., lot or batch).

- Identifier: Identifier code or key must be assigned to objects that exist within the retrieval system. Ideally, these identifiers must be defined in detail to a certain degree and globally unique. The identifiers used in the traceability system must be specified the type and structure used, and the system must find out how to associate identifiers with traceable resource units.

- Sharable data records: Product and process characteristics must be recorded either directly or indirectly associated with the identifier. These data records generated concerning the life cycle of a product will be shared among partners within the product supply chain to fulfill the retrieval goal.

- Accessibility of end-users: End users do not contribute too much to traceability data. However, they still play essential roles in confirming and using the product traceability data as the final link of a product supply chain. The goal of the traceability system is to provide information to end-users, to add value to their belief in traceable products.

- Two-way tracking: It will facilitate the traceability in confirming the information and accurate tracking, such as where the product comes from, and where it will be forwarded. Each partner in the product supply chain always needs these capabilities individually.

Traceability brings information about the overall view of a product's lifecycle before it reaches consumers. It must ensure that the recorded data is connected and moved from place to place without loss of identity.
Existing Domestic Traceability Solutions

In the past few years, several domestic traceability solutions have been increasingly developed, such as VNPT check, Agricheck, TraceVerified, iCheck, TEFOOD. These are current traceability solutions in the market, applying information technology to provide information on origin and product origin to consumers through stamps containing information on the product. Depending on the different solutions, the solution provider will use different types of stamps such as barcode stamps, QR codes, doublelayer stamp stamps, color stamps.

However, in general, due to these solutions have not been associated with Blockchain technology, there are still potential risks as analyzed in the previous section when the data center will be managed and controlled by providers, not users in the supply chain. Besides, depending on the designer, each solution will bring a different information standard to consumers.

\section{Blockchain and Its Potential Application in The Traceability System}

As mentioned above, the current traceability systems still exist challenges that need to be overcome, such as the possibility of a system being hacked to change data, the ability of data manipulation, difficulties in detecting bad products and identifying areas of influence, and standardizing traceability information not according to general standards.

Blockchain is known as a technology that can reinforce the value of trust in the world without mutual trust or authenticity ${ }^{7,8}$. There are some advantages of blockchain are as follows:

- Autonomy: It allows participants to have direct ownership and control of their data without being controlled or relying on any other organization or individual. Each owner has the right to manage and share his data.

- Anti-denial: It ensures that the information recorded is irrefutable. In other words, recorded data are sure of their owner and exist permanently.

- Brand protection ability: Blockchain system will define a clear profile of all existing entities: individuals, organizations, products, and data. The information recorded on Blockchain contributes to branding and reputation for manufacturers.

- Increasing competitive advantage through the transparency of origin: One of the characteristics of Blockchain is the ability to transparent 
information without fear of information being changed or deleted. Information from the time of generating and sharing on the network is unified. Therefore, consumers can trust the above information.

Thus, Blockchain technology applied to traceability tackles two current challenges: the ability of the system to be compromised by data changes and the ability to manipulate data.

In addition, the deployment of the traceability system in the supply chain requires all stakeholders to systematically connect the flow of materials, products, and information. This requires a common language, notably GS1 - the commercial language that is currently widespread across the world ${ }^{9,10}$. GS1 - GTS standards define trade rules: rules for creating product identification codes, identifying shipments, and exchanging trade packets. This language is also applied to define minimum requirements when designing and implementing a traceability system according to a global, unified standard.

\section{OUR APPROACH}

Based on the research results and surveys of projects related to traceability, we propose a framework prototype of the traceability system as a general template in the supply chain utilizing Blockchain technology and compliance with GS1 standards. In the trial version, this system will provide traceability for products that are quantifiable and unmodified throughout its supply chain.

Basically, each entity in the supply chain (raw material supplier, manufacturer, distributor, retailer, excluding consumers because this object does not act as a data provider) has a digital identifier on the Blockchain network. Identifiers are used by entities to publicize the identity on the network, and use when performing actions on the system.

Except for users, other entities in the system, including products, goods, and assets (tokens) circulated and exchanged in the supply chain, also have identifiers. The identity of a product will contain its information and related logs. Asset identification will record property ownership on the blockchain.

In addition, there must be a connection between digital identifiers and global identifiers with respect to GS1 by using a company number, product code, and shipment code.

\section{The Proposed Framework}

The proposed framework is designed under layerbased architecture model that consists of 3 typical layers as described in Figure 1.
The application layer provides web applications and multi-platform mobile applications for a supply chain ecosystem. The web application plays a management role in user rights, information provider for senior managers, individuals, and departments responsible for management in businesses and organizations. Data is collected decentralized and ensures the integrity of the entire network. Additionally, the web application also supports searching information when input is the product code (code can be directly scanned or imported). This code (in QR code format) is printed on the stamp and pasted on the product or traceable unit when shipping. The mobile applications act as log entries for products from the manufacturing process, processing, transportation, and other processes that take place in the supply chain. Besides, the mobile application also supports lookup of traceability information. The lookup function will exist on all implemented applications.

The processing core layer provides services to handle requests sent from the client and plays an intermediary role between user requests and Blockchain classes. The exchanged data format will comply with GS1 global standards. In order to interact with Blockchain and record historical data logs, we make many interconnected smart contracts to create high flexibility and scalability for many different supply chains.

The Blockchain layer supports various Blockchain platforms that are created for developers to build applications or can build their own Blockchain for network projects, depending on the purpose of use and transaction processing performance of the system. However, within the scope of the article, we propose using the Ropsten Network of Ethereum Blockchain ${ }^{11}$. This technology is one of the current leading Blockchain application development platforms, supporting the extremely powerful Smart Contract $^{12,13}$. It is easy to learn and convenient to build applications.

\section{Design of Smart Contracts}

The smart contract used in the system is divided into two main categories: one for identity and one for the digital asset (token). The smart contract of identifiers can be broken down into components that exist in a supply chain, including people, batches of products, and products. The one used to make digital assets exchanged online is broken down into two main categories, including fungible and non-fungible assets.

- Users participating in the system will be identified by ERC725 and ERC735. 


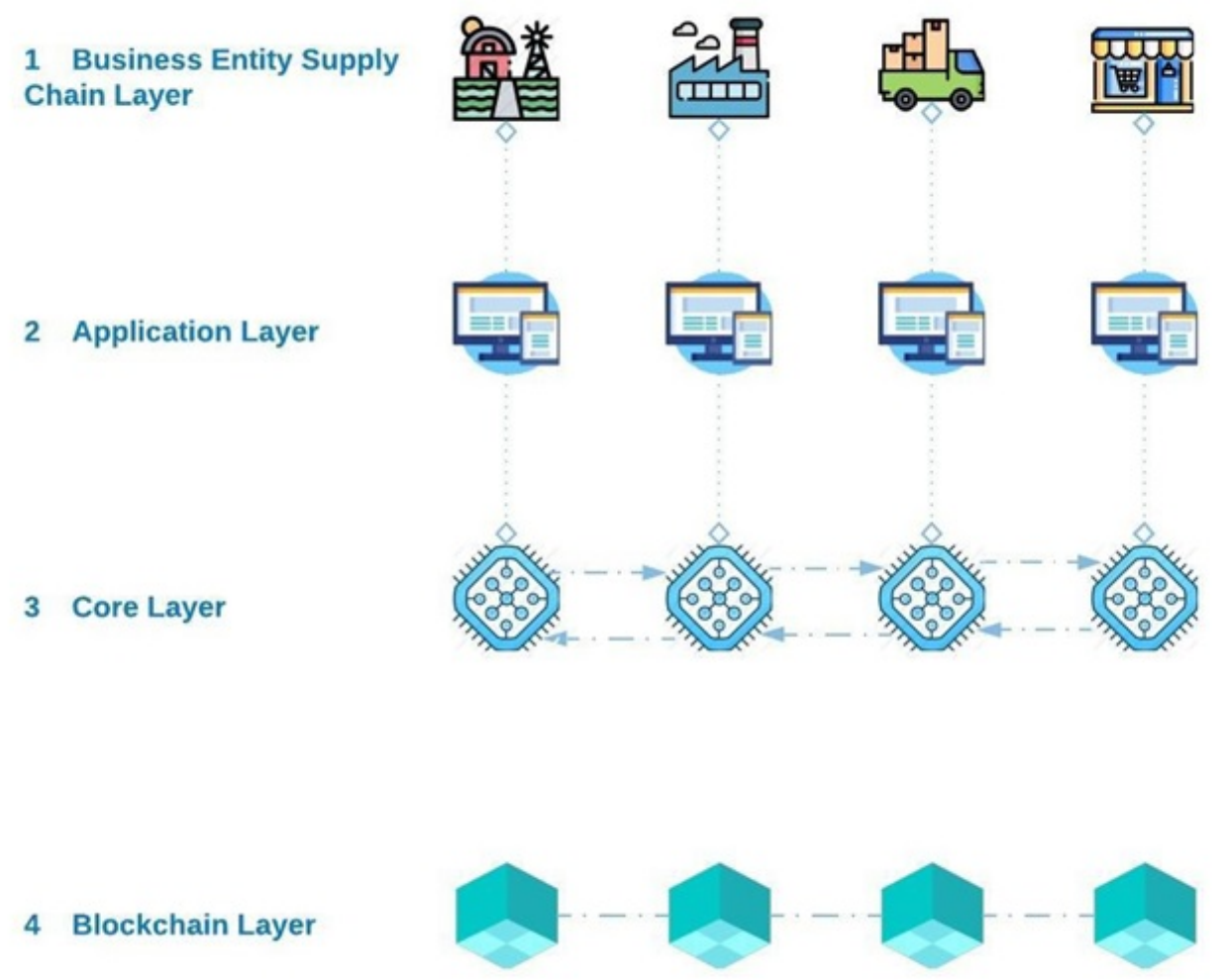

Figure 1: The proposed framwork for a traceability system

- The batch of products and products that exist in the system will be identified by ERC721.

- Digital assets connected to product lots, physical products and other exchanged assets will be implemented by ERC721 and ERC20.

- The origin data statements and logs will be recorded by ERC735 and ERC721.

\section{On-chain Data}

Blockchain plays a role as a database that records historical data, digital identity information, and ownership information. All essential data will be stored onchain such as GS1 identifier, production process log, shipping process log, asset exchange log, and product sales log.

\section{IMPLEMENTATION AND DISCUSSION}

\section{Implementation}

We have successfully implemented a trial version of the traceability system named VieFarm, as shown in Figure 2, using Blockchain that complies with GS1.
Additionally, our system is adjustable with various processes and supply chain models. Each partner of the system will use the web application to manage and lookup traceability information.

For tracking the origin and all related processing processes of a product, consumers (end-users) can use mobile phones to scan the QR-code directly on the product and see the source information of the product retrieved from Blockchain.

\section{Discussion}

After being used in the trial by different users, our system shows some advantages. Firstly, the information transparency of VieFarm is a crucial factor in creating trust between businesses and consumers. Instead of the previous belief value created by the brand, the application of Blockchain technology gives a new aspect of bringing trust for product consumers. Furthermore, shipments in the traceability system are assigned identifiers and associated with their traceability information. The traceability system provides a clear graph of a traceable shipment. Each node on the graph determines the path to it, the previous point, 


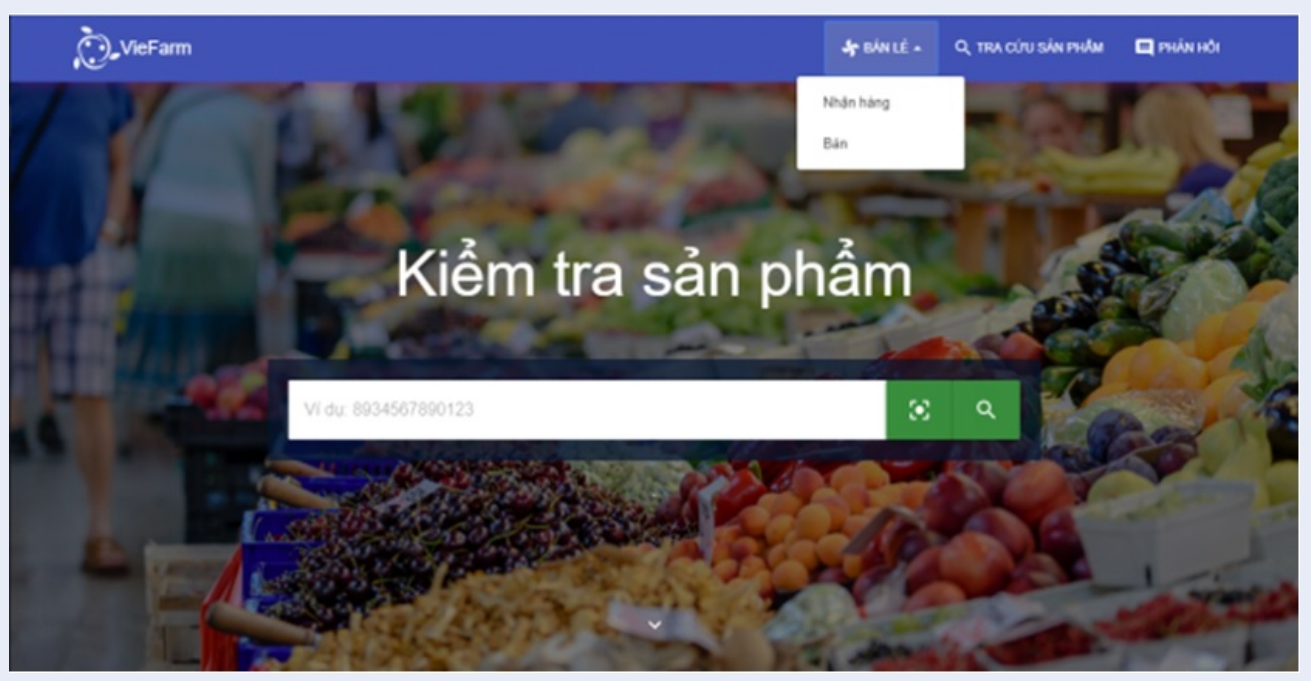

Figure 2: Product lookup interface of retail agents

and the following point that the product has passed through its life cycle. This will help products being tracked and traced from the farm to the consumer. Additionally, the statement made by the enterprise is the information stored on the Blockchain. Because of the data immutability of this technology, each enterprise must be responsible for its claims.

However, VieFarm also has some limitations that need to be resolved in our future work. The system is not tolerant of changes, which means that whenever anyone wants to modify the traceability data that has been stored on the Blockchain, the data creation object must re-create the data and take a new expense. Then, system privacy is no longer high. Therefore, when participating in the traceability system, all parties must agree to the trade-off between privacy and prestige based on publicly available and transparent data.

\section{CONCLUSION}

For the society, the traceability system using Blockchain and applying the global traceability GS1 standards helps to look up and verify the identity and origin of a product quickly and accurately. Besides, it also enhances the product value and improves consumer confidence in the community. At the same time, this solution can be widely applied in practice, creating smart consumer habits in the period of 4.0 technology. Furthermore, for scientific research, this paper also contributes and wishes to disseminate knowledge of Blockchain technology in the field of training and to build the Blockchain ecological community.

\section{ACKOWLEDGEMENT}

This research is funded by Ho Chi Minh City University of Technology (HCMUT), VNU-HCM under grant number T-KHMT-2018-89. We acknowledge the support of time and facilities from HCMUT, VNU-HCM for this study.

\section{CONFLICTS OF INTEREST}

The authors declare no conflict of interest.

\section{AUTHORS' CONTRIBUTION}

Hoai -Nam Nguyen conceived the study, implemented trial software, and wrote the manuscript.

Minh-Thinh Le implemented trial software and performed experiments.

Duc-Hiep Nguyen designed the framework and wrote the manuscript.

Thanh-Van Le conceived the study and wrote the manuscript.

Nguyen Huynh-Tuong conceived the study and wrote the manuscript.

Hoang-Anh Pham conceived the study, desgined the framework, and finalized the manuscript.

\section{REFERENCES}

1. Ioanna CP, Constantine I, Theofilos $\mathrm{M}$. What determines the acceptance and use of electronic traceability systems in agrifood supply chains? 2018;Available from: https://doi.org/10. 1016/j.jrurstud.2018.01.001.

2. Dabbene F, Gay P. Food traceability systems: Performance evaluation and optimization. Computers and Electronics in Agriculture. 2011;75(1):139-146. Available from: https://doi. org/10.1016/j.compag.2010.10.009. 
3. Olsen P, Borit M. How to define traceability. Trends in Food Science \& Technology. 2013;29(2):142-150. Available from: https://doi.org/10.1016/j.tifs.2012.10.003.

4. Folinas D, Manikas I, Manos B. Traceability data management for food chains. British Food Journal. 2006;108(8):622-633. Available from: https://doi.org/10.1108/00070700610682319.

5. Fritz $M$, Schiefer $G$. Tracking, tracing, and business process interests in food commodities: A multi-level decision complexity. International Journal of Production Economics. 2009;117(2):317-329. Available from: https://doi.org/10.1016/ j.ijpe.2008.10.015.

6. Storoy J, Thakur M, Olsen P. The TraceFood Framework - Principles and guidelines for implementing traceability in food value chains. Journal of Food Engineering. 2013;115(1):41-48. Available from: https://doi.org/10.1016/j.jfoodeng.2012.09.018.
7. Swan M. Blockchain Blueprint For A New Economy. O'Reilly Media Inc. 2015;p. 9-11.

8. Bahga A, Madisetti V. Blockchain Application A Hands-On Approach. 2017;

9. GS1 AISBL, GS1 General Specifications. Vietnam Education Publishing. 2018;.

10. GS1-GTS, GS1 Global Traceability Standard. 2017;

11. Wood G. Ethereum: A Secure Decentralized Generalised Transaction Ledger. 2018;Available from: https://gavwood. com/paper.pdf.

12. Szabo N. Smart Contracts: Building Blocks for Digital Markets. 2017;

13. Smart Contract: What is smart contract? ;Available from: https://blockchainhub.net/smart-contracts/. 


\title{
Ứng dụng Blockchain cho truy xuất nguồn gốc tương thích với chuẩn GS1
}

\author{
Nguyễn Hoài Nam ${ }^{1,2}$, Lê Minh Thịnh ${ }^{1,2}$, Nguyễn Đức Hiệp ${ }^{1,2}$, Lê Thanh Vân ${ }^{1,2}$, Huỳnh Tường Nguyên ${ }^{1,2}$, \\ Phạm Hoàng Anh ${ }^{1,2, *}$
}

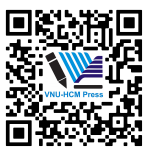

Use your smartphone to scan this

QR code and download this article

${ }^{1}$ Trương Đại học Bách Khoa TP.HCM

${ }^{2} Đ a ̣ i$ học Quốc gia Thành phố Hồ Chí Minh

Liên hệ

Phạm Hoàng Anh, Trường Đại học Bách Khoa TP.HCM

Đại học Quốc gia Thành phố Hồ Chí Minh

Email: anhpham@hcmut.edu.vn

Lịch sử

• Ngày nhận: 27-7-2019

- Ngày chấp nhận: 23-8-2019

- Ngày đăng: 17-10-2020

DOI :10.32508/stdjet.v3iSI1.514

\section{Check for updates}

\section{Bản quyền}

(c) ĐHQG Tp.HCM. Đây là bài báo công bố mở được phát hành theo các điều khoản của the Creative Commons Attribution 4.0 International license.

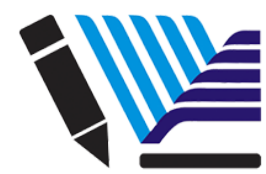

VNU-HCM Press

\section{TÓM TẮT}

Truy xuất nguồn gốc không chỉ đáp ứng nhu cầu xã hội về minh bạch thông tin sản phẩm và củng cố niềm tin của người tiêu dùng, mà còn đáp ứng nhu cầu của các doanh nghiệp để bảo vệ thương hiệu và tăng cường cạnh tranh trên thị trường. Một hệ thống truy xuất nguồn gốc thu thập mọi thông tin cẩn thiết ở mọi giai đoạn trong chuỗi cung ứng, nên nó cũng là một công cụ hiệu quả để theo dõi và tối ưu hóa quy trình sản xuất. Áp dụng công nghệ thông tin để số hóa quy trình nghiệp vụ là xu hướng tất yếu để nâng cao hiệu quả trong quản lý thông tin và đặc biệt là nhanh chóng phát hiện các vấn đề gian lận. Tuy nhiên, với quy trình số hóa bởi một hệ thống phần mềm máy tính, thách thức vẫn là liệu dữ liệu số hóa có thật hay không. Thực tế cho thấy việc thay đổi dũ liệu kỹ thuật số dễ dàng hơn dũ liệu trên giấy. Do đó, cần có một quy trình số hóa và cơ chế bảo mật nhằm đảm bảo tính minh bạch, chính xác và đông nhất của dữ liệu để từ đó phát hiện và theo dõi sự cố hiệu quả hơn. Blockchain là một công nghệ mới nổi đã thu hút nhiều sự chú ý sau thành công rất lớn trong lĩnh vực tài chính bởi các tính năng vượt trội trong việc ngăn chặn thay đổi dũ liệu kể cả từ phía bên trong hệ thống. Về mặt kỹ thuật, Blockchain là một sổ cái ghi lại toàn bộ lịch sử giao dịch trên một mạng máy tính ngang hàng theo thời gian. Một sổ cái chung sẽ được chia sẻ giữa tất cả các đối tương trong một hệ sinh thái để đảm bảo tính bất biến của dữ liệu và chống chối bỏ trách nhiệm, từ đó tăng cường tính minh bạch của dữ liệu. Do đó, áp dụng công nghệ Blockchain sẽ cải thiện quy trình truy xuất nguồn gốc hiện tại trong nông nghiệp bằng cách tăng trách nhiệm của các đối tượng trong quy trình và minh bạch thông tin cho người tiêu dùng. Trong bài báo này, chúng tôi sẽ đề xuất một khung sườn ứng dụng công nghệ Blockchain để tăng cường cho các hệ thống truy xuất nguôn gốc. Ngoài ra, khung đề xuất của chúng tôi đáp ứng tiêu chuẩn truy xuất nguô̂n gốc GS1 để đạt được độ tin cậy và khả năng tương thích cao với các hệ thống truy xuất nguôn gốc trên phạm vi toàn cầu.

Từ khoá: Truy xuất nguốn gốc, Blockchain, Độ tin cậy, Tính minh bạch
Trích dẫn bài báo này: Nam N H, Thịnh $L$ M, Hiệp N D, Vân L T, Nguyên $H$, Anh $P H$. Úng dụng Blockchain cho truy xuất nguồn gốc tương thích với chuẩn GS1. Sci. Tech. Dev. J. - Eng. Tech.; 3(S1): SI10-SI16. 